\title{
Extrapolating the bypass potential of treated Madre de agua (Trichanthera gigantea Nees) leaf meal as protein source in Rumen-Fistulated Brahman Cattle
}

\author{
Angelo Francis F. Atole ${ }^{1}$ and Lolito C. Bestil
}

\begin{abstract}
This study assessed the effectiveness of formaldehyde, heat, and tannic acid treatments of madre de agua leaf meal (MALM) in reducing the degradation of dry matter (DMD) and crude protein (CPD) in the rumen for increased supply of bypass protein at the intestinal level. The experiment utilized a rumen-fistulated Brahman bull fed with chopped Napier grass soilage (basal diet) and MALM (test diet) at 70:30 basal:test diet ratio. Nylon bags (porosity of $\pm 53 \mu \mathrm{m}$ ) containing the treated MALM were incubated in the rumen for 24,48 and $72 \mathrm{~h}$ following the "sequential addition" method for in situ degradation measurement.

Results showed that DMD of MALM was significantly reduced by formaldehyde treatment after $24 \mathrm{~h}$ and $48 \mathrm{~h}$ period of incubation than the untreated. This was followed by tannic acid treatment, though the reduction was significant only after $48 \mathrm{~h}$ incubation than the untreated. At $72 \mathrm{~h}$ period of incubation, DMD remained to be significantly lowest with formaldehyde treatment than the untreated or heat and tannic acid treatments. A similar pattern of differences in DMD rate $(\% / \mathrm{h})$ was observed as that of DMD (\%). The CPD of MALM was also significantly reduced with formaldehyde treatment after $24 \mathrm{~h}$ incubation than the untreated. At $48 \mathrm{~h}$ incubation, all treatment methods showed significant protection of protein in MALM over that of the untreated. At $72 \mathrm{~h}$, formaldehyde and heat treatments significantly reduced the CPD of MALM compared to the untreated. A similar pattern of differences in CPD rate $(\% / h)$ was observed as that of CPD (\%). Among treatment methods, the use of formaldehyde is the best, followed by tannic acid treatment, in achieving rumen bypass and promoting greater amino acid supply at the intestinal level.
\end{abstract}

Keywords: bypass protein, in situ degradation, cattle, formaldehyde, heat, tannic acid

*Department of Animal Science, College of Agriculture and Food Science, Visayas State University, Visca, Baybay City, Leyte 6521-A Philippines

${ }^{1}$ Department of Animal Science, College of Agriculture \& Natural Resources, Central Bicol State University of Agriculture, San Jose, Pili, Camarines Sur

*Corresponding Author. Address: Department of Animal Science, College of Agriculture and Food Science, Visayas State University, Visca, Baybay City, Leyte 6521-A Philippines; Email:Iolitobestil@vsu.edu.ph

DOI:10.32945/atr4113.2019 
Extrapolating the bypass potential of treated madre de agua

\section{INTRODUCTION}

One of the promising shrubs for livestock feeding because of its high protein and calcium contents with low contents of condensed tannins, is madre de agua (Trichanthera gigantea Nees) that originates from Colombia (Rosales 1996) but is now locally available. The leaves of madre de agua contain up to $22 \%$ crude protein (CP), and most of this is true protein with good amino acid balance compared to other fodder trees (Rosales et al 1992). Furthermore, madre de agua has considerable amounts of water soluble carbohydrates $\left(43.2 \mathrm{~g} \mathrm{~kg}^{-1} \mathrm{DM}\right)$, starch $\left(248.2 \mathrm{~g} \mathrm{~kg}^{-1} \mathrm{DM}\right)$, total sugars $\left(170.1 \mathrm{~g} \mathrm{~kg}^{-1} \mathrm{DM}\right)$, and reducing sugars $\left(91.6 \mathrm{~g} \mathrm{~kg}^{-1} \mathrm{DM}\right)$, making it a good source of energy as well (Rosales 1996). While the forage of madre de agua is highly fermentable compared to forages of other fodder trees and shrubs, showing high in sacco degradability at $52-77 \%$ for a $24 \mathrm{~h}$ incubation (Angel 1988), it provides lesser amount of protein reaching the small intestines, reducing its potential as source of by-pass protein. Therefore, efforts to protect the protein of madre de agua from microbial degradation in the rumen should be explored to increase the direct supply of amino acids for absorption in the small intestines.

Several treatment methods have been reported to be effective in protecting the protein in various feed sources from microbial degradation in the rumen (Castro et al 2007, Shamoon et al 2009). The use of heat, tannic acid, and formaldehyde treatments for soybean meal significantly reduced the dry matter degradability (DMD) and crude protein digestibility (CPD) in the rumen of cattle (Atole \& Bestil 2014). Similar results were found in other feed resources subjected to such treatments in cattle (Nagel et al 1992, Castro et al 2007). However, none has been done to protect the protein in madre de agua leaf meal (MALM) even with its great potential as a source of less costly bypass protein such as soybean meal or fish meal in ruminants because of its good amino acid balance. Hence, this study was conducted to compare the effectiveness of heat, formaldehyde, and tannic acid treatments in protecting the protein in MALM, extrapolated from in situ rumen degradability in cattle.

\section{MATERIAL AND METHODS}

\section{Preparation and Conditioning of the Animal}

A yearling Brahman bull weighing 200kg bodyweight (BW) fitted with rumen fistula (Bar Diamond Lane, Parma, ID, USA) was used in the in situ degradation trial. A month before the experiment, the bull was confined and closely monitored for health conditions, dewormed against internal and external parasites with Albendazole (Pfizer, Inc.) at $1 \mathrm{~mL} 10 \mathrm{~kg}^{-1} \mathrm{BW}$ given orally and Ivermectin (Merial, Inc.) at $1 \mathrm{~mL}^{2} \mathrm{~kg}^{-1} \mathrm{BW}$ injected subcutaneously.

The bull was fed with $70 \%$ freshly-chopped Napier grass (Pennisetum purpureum Schumach.) and 30\% MALM based on the use of protein sources as supplement (Preston 1986) for 10 days. The amount of the basal diet and the supplement was computed based on the $5.4 \mathrm{~kg}$ DM intake/day equivalent to $2.7 \%$ BW daily DM intake requirement of a $200 \mathrm{~kg}$ bull (Kearl 1982). Feeding was done daily at $8 \mathrm{am}$ and $4 \mathrm{pm}$ with free access to clean drinking water. Two days before the nylon bags were placed inside the rumen, the diet was reduced into half to 
accommodate the bags and to make its recovery easier (Playne et al 1978). After the degradation trial, the bull was back into full-feeding considering its daily DM intake requirement.

\section{Preparation of MALM and the dietary treatments}

Fresh madre de agua leaves were harvested, sundried until $12-14 \%$ moisture (86-88\% DM) was reached, and hammer-milled through an $8 \mathrm{~mm}$ screen to produce the MALM. The MALM was treated with heat, formaldehyde, and tannic acid (Merck, Germany) at the Animal Nutrition Laboratory of the Department of Animal Science, Visayas State University. Heat treatment was accomplished by placing the MALM in an oven set at $149^{\circ} \mathrm{C}$ for four hours (Glimp et al 1967). The formaldehyde treatment was accomplished by spraying and mixing $10 \mathrm{~mL}$ of formaldehyde solution per $100 \mathrm{~g}$ MALM (Hemsley et al 1970); the solution was prepared by adding $9 \mathrm{~mL}$ water to one gram formaldehyde. Tannic acid treatment was done by wetting the $100 \mathrm{~g}$ of MALM with $5 \mathrm{~mL}$ water, then mixing $9 \mathrm{~g}$ of tannic acid powder and letting it stand for $30 \mathrm{~min}$ (Hatfield et al 1969). The treated material was then covered with a coarse cloth for three days for the chemicals to react on the feed material and equilibrate with air at room temperature (Nishimuta et al 1974). The formaldehyde and tannic acidtreated madre de agua leaf meal (F-MALM \& T-MALM) were then dried to contain about $12-14 \%$ moisture, similar to the heat-treated (H-MALM) and the untreated (UMALM).

\section{Rumen incubation of treated MALM and chemical analysis}

Nylon bags with a pore size of $\pm 53 \mu \mathrm{m}$ and measuring $5 \times 10 \mathrm{~cm}$ (Bar Diamond Lane, Parma, Idaho, USA) were oven-dried at $65^{\circ} \mathrm{C}$ for $30 \mathrm{~min}$ and weighed (Osuji et al 1993). Approximately 3.5 to $4.0 \mathrm{~g}$ of samples subjected to the various treatments and the U-MALM were placed into the nylon bags and were sealed with a heat sealer. The nylon bags containing the samples were then placed inside a lingerie bag with stainless steel weights to ensure that the nylon bags stay submerged in the rumen fluid instead of floating that may give unpredictable degradation rates (Preston 1986). Three sets of bags containing the treatments were incubated (24h, $48 \mathrm{~h} \& 72 \mathrm{~h}$ ) to determine degradation rate (\%/hour). The "sequential addition" method was used to lessen disturbance of the rumen by putting on first the $72 \mathrm{~h}$ samples; then the $48 \mathrm{~h}$ samples on the next day and the $24 \mathrm{~h}$ samples on the third day. Then all the bags were recovered at the same time on the fourth day (Osuji et al 1993). With three replicates each, there were 12 nylon bags incubated inside the rumen per $24 \mathrm{~h}$ period, or a total of 36 nylon bags were collected. The collected nylon bags were then thoroughly washed by scrubbing gently for $30 \mathrm{~min}$ in a running tap water until the water ran clear, then oven-dried for $48 \mathrm{~h}$ at $60^{\circ} \mathrm{C}$ and were weighed immediately using a digital analytical balance (TE214S, Sartorius, AG Gottingen). The CP content of the incubated MALM was analyzed in the macro-Kjeldahl digestion and distillation apparatus and \% CP was calculated as \%Nx6.25 (AOAC 1993). Then, DMD and CPD were calculated using the following formula:

$$
\operatorname{DMD}(\%)=\frac{\text { SWa }- \text { SWb }}{\text { SWa-Weight of nylon bag }} \times 100
$$


Extrapolating the bypass potential of treated madre de agua

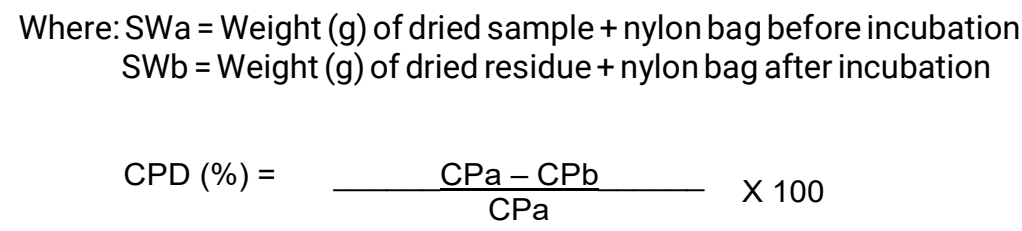

Where: $\mathrm{CPa}=\mathrm{CP}$ of dry feed sample $(\mathrm{g})$ before incubation $\mathrm{CPb}=\mathrm{CP}$ of dry feed residue $(\mathrm{g})$ after incubation

Data were analyzed using two-way analysis of variance (ANOVA), and differences among treatment means were compared using Tukey's Honestly Significant Difference (HSD) test in the Statistical Package for Social Sciences, ver. 17 computer program.

\section{RESULTS AND DISCUSSION}

\section{Rumen Dry Matter Degradation of Madre de Agua Leaf Meal}

The in situ DMD and DMDR of treated and untreated MALM incubated in the rumen of cattle is presented in Table 1. At 24h incubation, only F-MALM showed significantly lower DMD and DMDR, although other treatments (tannic acid \& heat) showed reduced DMD and DMDR, than the untreated MALM. A similar pattern of differences was obtained with $48 \mathrm{~h}$ and $72 \mathrm{~h}$ incubation period. Across periods of incubation, formaldehyde treatment appeared to be the most effective in reducing rumen degradation of MALM, followed by tannic acid treatment.

The effectiveness of formaldehyde treatment is supported by Shamoon et al (2009) who stated that formaldehyde alters the rumen environment and microbial activities, thus reducing degradation of energy and proteins of the feed. They added that the digestibility of dry matter, organic matter, acid detergent fiber, and neutral detergent fiber, were also limited when the ration is treated with formaldehyde. Snyman (1993) also found that treating green-chopped forage with formaldehyde prevented the in vitro degeneration of nutrients by limiting the disintegration of water-soluble carbohydrates and protein of the feed. Similarly, Gareab (1986) supported that formaldehyde treatment also protects fat from excessive microbial degradation in the rumen so that the amount of bypass fat that are hydrolyzed and absorbed in the small intestines is increased. Tannic acid treatment can also effectively protect the substrate from rumen degradation (McMahon et al 2000) and, aside from protein, it also protects other feed constituents such as hemicellulose, cellulose, starch, and pectin by decreasing the nutrient availability in the rumen (Schofield et al 2001). 
Atole \& Bestil

Table 1. In situ dry matter degradation (\%) and degradation rate $(\% / h)$ of treated and untreated madre de agua leaf meal at varying incubation periods in Brahman cattle

\begin{tabular}{lccccc}
\hline Parameters & U-MALM $^{3}$ & H-MALM $^{4}$ & F-MALM $^{5}$ & T-MALM $^{6}$ & p-value \\
\hline DMD (\%) & & & & & \\
$24 \mathrm{~h}$ & $43.74^{\mathrm{b}}$ & $41.06^{\mathrm{ab}}$ & $37.73^{\mathrm{a}}$ & $39.58^{\mathrm{ab}}$ & 0.017 \\
$48 \mathrm{~h}$ & $68.83^{\mathrm{b}}$ & $66.13^{\mathrm{b}}$ & $59.19^{\mathrm{a}}$ & $60.82^{\mathrm{a}}$ & 0.001 \\
$72 \mathrm{~h}$ & $70.38^{\mathrm{b}}$ & $69.28^{\mathrm{b}}$ & $64.24^{\mathrm{a}}$ & $67.76^{\mathrm{b}}$ & 0.001 \\
DMDR(\%/hr) & & & & & \\
$24 \mathrm{~h}$ & $1.82^{\mathrm{b}}$ & $1.71^{\mathrm{ab}}$ & $1.57^{\mathrm{a}}$ & $1.65^{\mathrm{ab}}$ & 0.017 \\
$48 \mathrm{~h}$ & $1.43^{\mathrm{b}}$ & $1.38^{\mathrm{b}}$ & $1.23^{\mathrm{a}}$ & $1.27^{\mathrm{a}}$ & 0.001 \\
$72 \mathrm{~h}$ & $0.98^{\mathrm{b}}$ & $0.96^{\mathrm{b}}$ & $0.89^{\mathrm{a}}$ & $0.94^{\mathrm{b}}$ & 0.001 \\
\hline
\end{tabular}

Means of similar letter-superscripts within a row are not significantly different.

'Drymatter degradation $\quad{ }^{4}$ Heat-treated madre de agua leaf meal

${ }^{2}$ Dry matter degradation rate $\quad{ }^{5}$ Formaldehyde-treated madre de agua leaf meal

${ }^{3}$ Untreated madre de agua leaf meal $\quad{ }^{6}$ Tannic acid-treated madre de agua leaf meal

As madre de agua contains high amounts of water-soluble carbohydrates, sugars and starch, with relatively low neutral detergent fiber, and its tannins are of the hydrolysable type rather than condensed (Rosales 1996), this should explain why the solubility of untreated MALM was high enough to cause a significant reduction in the in situ degradation of MALM by formaldehyde and tannic acid treatment.

\section{Rumen Crude Protein Degradability of Madre de Agua Leaf Meal}

Table 2 shows the in situ CPD and CPDR of treated and untreated MALM in the rumen of Brahman cattle. While all treatment methods were able to reduce the CPD and CPDR, only formaldehyde treatment of MALM significantly reduced the CPD and CPDR at $24 \mathrm{~h}$ period of rumen incubation as compared to that of the untreated. At $48 \mathrm{~h}$ period of rumen incubation, all treatments caused significant reduction in the CPD and CPDR compared to the untreated, while at $72 \mathrm{~h}$ period, only formaldehyde and heat-treated MALM showed significantly lower CPD and CPDR as compared with the untreated. Across periods, formaldehyde treatment of MALM resulted to a significantly lower CPD and CPDR as compared to that of heat and tannic acid treatments and showed the longest protection of protein of MALM against microbial degradation in the rumen.

In an experiment with silage, formaldehyde treatment can reduce the protein degradability by forming crosslinks between protein chains (Nagel et al 1992) or by altering the bacterial population in the rumen (Woolford 1975). The effectiveness of formaldehyde treatment in reducing protein degradability in the rumen was also reported in soybean meal (Atole \& Bestil 2014). The greatest potential of protection provided by formaldehyde treatment on $\mathrm{CP}$ degradation was also confirmed in other studies (Hiristor et al 2004, Nagel et al 1992, Shamoon et al 2009). In a trial with formaldehyde-treated herbage, proteolysis and apparent nitrogen digestibility in growing sheep were decreased, thus nitrogen retention was increased (Nagel et al 1992). With formaldehyde-treated ration, Shamoon et al (2009) reported that the ratio between rumen degradable and rumen undegradable proteins was high (55.45-63.37\%) compared to the untreated ration (20.80-24.76\%). 
Extrapolating the bypass potential of treated madre de agua

Table 2. In situ crude protein degradation (\%) and degradation rate $(\% / \mathrm{h})$ of treated and untreated madre de agua leaf meal at varying incubation periods in Brahman cattle

\begin{tabular}{cccccc} 
Parameters & U-MALM $^{3}$ & H-MALM $^{4}$ & F-MALM $^{5}$ & T-MALM $^{6}$ & p-value \\
\hline CPD (\%) & & & & & \\
$24-h$ & $61.20^{\mathrm{b}}$ & $52.59^{\mathrm{ab}}$ & $49.65^{\mathrm{a}}$ & $57.13^{\mathrm{ab}}$ & 0.019 \\
$48-\mathrm{h}$ & $77.79^{\mathrm{c}}$ & $72.90^{\mathrm{b}}$ & $66.32^{\mathrm{a}}$ & $71.46^{\mathrm{b}}$ & 0.001 \\
72-h & $82.44^{\mathrm{c}}$ & $79.10^{\mathrm{b}}$ & $72.97^{\mathrm{a}}$ & $80.66^{\mathrm{bc}}$ & 0.001 \\
CPDR(\%/hr) & & & & & \\
24-h & $2.55^{\mathrm{b}}$ & $2.19^{\mathrm{ab}}$ & $2.07^{\mathrm{a}}$ & $2.38^{\mathrm{ab}}$ & 0.019 \\
$48-\mathrm{h}$ & $1.62^{\mathrm{c}}$ & $1.52^{\mathrm{b}}$ & $1.38^{\mathrm{a}}$ & $1.49^{\mathrm{b}}$ & 0.001 \\
$72-\mathrm{h}$ & $1.14^{\mathrm{c}}$ & $1.10^{\mathrm{b}}$ & $1.01^{\mathrm{a}}$ & $1.12^{\mathrm{bc}}$ & 0.001 \\
\hline
\end{tabular}

Means of similar letter-superscripts within a row are not significantly different

${ }^{1}$ Crude protein degradation $\quad{ }^{4}$ Heat-treated madre de agua leaf meal

${ }^{2}$ Crude protein degradation rate $\quad{ }^{5}$ Formaldehyde-treated madre de agua leaf meal

${ }^{3}$ Untreated madre de agua leaf meal $\quad \quad{ }^{6}$ Tannic acid-treated madre de agua leaf meal

While being seen as inferior to formaldehyde treatment, heat and tannic acid treatments appeared to be significantly superior to that of the untreated on reducing the CPD and CPDR of MALM especially in the $48 \mathrm{~h}$ and $72 \mathrm{~h}$ periods. The findings of Castro et al (2007) and Atole and Bestil (2014) that showed protection of protein in soybean meal against rumen microbial degradation by heat and tannic acid treatments are in accord with the results of this study. Heat treatment of a protein feedstuff blocks the reactive sites for microbial proteolytic enzymes (Broderick \& Craig 1980), while tannic acid treatment changes the ruminal fermentation pattern of proteins (Frutos et al 2004). Accordingly, Bateman et al (2005) reported that heat treatment of protein feedstuffs reduces protein degradation in the rumen thereby increasing the amount of dietary protein escaping rumen degradation and increasing the amino acid pool entering the small intestines for absorption.

With treated MALM, the high amounts of rumen undegradable protein that escaped microbial degradation may supply greater amounts of bypass protein in the small intestines. Similarly, Tagari et al (1986) hypothesized that the high amounts of rumen undegradable protein may increase the supply of dietary protein in the duodenum, allowing more amino acids that will be absorbed and utilized by ruminants for optimum production. Relatedly, the findings of Shamoon et al 2009 and Hiristor et al 2004 with formaldehyde-treated diets confirm that the more proteins digested and absorbed in the small intestines, the better is the animal performance in terms of faster gains, improved feed efficiency, and decreased feed costs. In contrast, the absence of protection from microbial degradation in the rumen of U-MALM increased protein solubility, thus, increasing the CPD and CPDR of the U-MALM in the rumen.

\section{CONCLUSION AND RECOMMENDATION}

Treating MALM with heat and tannic acid can provide a longer protection against excessive microbial degradation in the rumen, but treating MALM with formaldehyde can provide the greatest protection for a higher supply of bypass protein. It is, therefore, recommended to use formaldehyde treatment for protecting 
the protein in forages, but if there is any concern on voluntary intake of such forage once fed to the animals, the use of heat and tannic acid treatment can be used as alternatives. It is further recommended to conduct this trial on other ruminant species to determine the efficacy of these treatment methods on different species in terms of rumen environment or feeding habit, more effectively if circumstances allow measurement of the amount of bypass protein entering the small intestines and that excreted in the feces to provide a detailed measure of the efficacy of formaldehyde treatment on MALM against microbial degradation in the rumen.

\section{ACKNOWLEDGMENT}

The researchers would like to thank the Commission on Higher Education for the financial assistance provided in this study and to the Visayas State University for the use of animals and facilities. We also extend our gratitude to Professors Serena L. Sanchez and Alfredo B. Escasinas for their comments and suggestions, and to Dr. Remberto A. Patindol for his assistance in the statistical analysis of data.

\section{REFERENCES}

Angel JE. 1988. Avances en la evaluacion de recursos nutricionales tropicales en Colombia. In Reporte de Investigacion 1(1) (pp26). CIPAV, Cali, Colombia

Atole AFF and Bestil LC. 2014. Extrapolating bypass protein potential of treated soybean meal by in situ degradation in rumen-fistulated Brahman cattle. Annals of Tropical Research 36(1):50-62

Bateman HG, Clark JH \& Murphy MR. 2005. Development of a system to predict feed protein flow to the small intestine of cattle. Journal of Dairy Science 88:282-295

Broderick GA and Craig WM. 1980. Effect of heat treatment on ruminal degradation and escape and intestinal digestibility of cottonseed meal. The Journal of Nutrition 110(12):2381-2389

Castro SB, Philip LE, Lappiere H, Jardon PW \& Berthiaume R. 2007. Ruminal degradability and intestinal digestibility of protein and amino acids in treated soybean meal products. Journal of Dairy Science 90(2):810-822

Frutos P, Hervas G, Giráldez FJ \& Mantecon AR. 2004. Review. Tannins and ruminant nutrition. Spanish Journal of Agricultural Research 2(2):191-202

Gareab FH. 1986. Digestive physiology and ruminant Nutrition. Part2. College of Agriculture-University of Basrah

Glimp HA, Karr MR, Little CO, Woolfolk PG, Mitchell JR GE \& Hudson LW. 1967. Effect of reducing soybean protein solubility by dry heat on the protein utilization of young lambs. Journal of Animal Science 26(4): 858-861

Hatfield EE, Driedger A, Garrigus US, Lamb PE \& Doane BB. 1969. Effect of treating soybean meal with tannins. Beef Day Report. University of Illinois, UrbanaChampaign

Hemsley JA, Hogan JP \& Weston TH. 1970. Protection of forage protein from ruminal degradation. Proceedings of the XI International Grassland Congress (pp703-6). Australia

Hiristov AN, Etter RP, Ropp JK \& Granden KL. 2004. Effect of dietary crude protein level and degradability on ruminal fermentation and nitrogen utilization in 
Extrapolating the bypass potential of treated madre de agua

lactating dairy cow. Journal of Animal Science 82(11):3219-3229

Kearl LC. 1982. Nutrient requirements of ruminants in developing countries. International Feedstuffs Institute, Utah Agricultural Experiment Station, Utah University, Logan, Utah

McMahon LR, McAllister TA, Berg BP, Majak W, Acharya SN, Popp JD, Coulman BE, Wang $Y$ \& Cheng KJ. 2000. A review of the effects of forage condensed tannins on ruminal fermentation and bloat in grazing cattle. Canadian Journal of Plant Science 80(3):469-485

Nagel SA and Broderick GA. 1992. Effect of formic acid or formaldehyde treatment of alfalfa silage on nutrient utilization by dairy cows. Journal of Dairy Science 75(1):140-154

Nishimuta JF, Ely DG \& Boling JA. 1974. Ruminal bypass of dietary soybean protein treated with heat, formalin and tannic acid. Journal of Animal Science 35(5):952-957

Osuji PO, Nsahlai IV \& Khalili H. 1993. Feed evaluation. ILCA manual 5. ILCA (International Livestock Centre for Africa), Addis Ababa, Ethiopia (pp40). Roughages. ILRI experience. Animal Feed Science and Technology 69(1-3): 2738

Playne MJ, Khumnualthong W \& Echevarria MG.1978. Factors affecting the digestion of oesophageal fistula samples and hay samples in nylon bags in the rumen of cattle. The Journal of Agricultural Science 90(1):193-204

Preston TR. 1986. Better utilization of crop residues and by-products in animal feeding: Research guidelines 2. A practical manual for research workers. Food and Agriculture Organization Animal Production and Health Paper 50 (pp2-10)

Rosales M, Preston TR \& Vargas JE. 1992. Advances in the characterization of non conventional resources with potential use in animal production. British Society of Animal Production. Animal Production in Developing Countries 16: 228-229

Rosales M. 1996. In vitro assessment of the nutritive value of mixtures of leaves from tropical fodder trees (PhD dissertation). University of Oxford

Schofield P, Mbugua DM \& Pell AN. 2001. Analysis of condensed tannins: a review. Animal Feed Science and Technology 91(1-2):21-40

Shamoon SA, Saleh MN \& Abbo NY. 2009. Effects of different levels of protein treated with formaldehyde on nutrients digestibility and some rumen and blood parameters in Awassi sheep. Iraqi Journal of Veterinary Sciences 23(2):169173

Snyman LD. 1993. Effect of exposure on the chemical composition and in vitro dry matter digestibility of untreated and formalin treated green chop. Animal Feed Science and Technology 44(3-4):275-280

Tagari H, Pena F \& Satter LD. 1986. Protein degradation by rumen microbes of heattreated whole cottonseed. Journal of Animal Science 62(6):1732-1736

Woolford MK. 1975. Microbiological screening of food preservatives, cold sterilants and specific antimicrobial agents as potential silage additives. Journal of the Science of Food and Agriculture 26(2):229-237 